\title{
Cession Contract - Abstract Action Deal
}

\author{
Vita Nemenova \\ Judge of Daugavpils Court of Arbitration, Riga Stradinǧ University (RSU) doctoral studies in Law \\ Email: vitanemenova@gmail.com
}

\section{Doi:10.5901/mjss.2014.v5n23p626}

\section{Abstract}

The aim of the article is to analyze the cession agreement from the point of view of the law theory. In the paper, the author considers the issue on cession agreement's nature and turns to two opinions - cession agreement is an abstract or a causal transaction. In the paper, the views of various law scientists in connection with the concerned issues are considered and analyzed. Attention is paid to the opinions of such European law scientists like Dernburg H., Toor A., Leonhard F., Larenc K., Koziol H., Welser R., Keller M., Schöbi Ch., Norr.K., Scheyhing.R, Poggeerl W., Palandt O. Such ideas in the field of law interpretation of the Russian scientists like Krasheninnikov E.A., Belov V.A., Krotov M.V., Sukhanov E., Vaskovskii E., Tuzov $D$., are explored. The author concludes that there are different opinions in interpreting of the law theory and legislation. The opinion on the abstract nature of cession agreement is absolutely dominant among the representatives of the German civil law scientists. In Austria's civil law science, this agreement basing on the positive law prescripts is traditionally described as a causal transaction. Among the representatives of civil law scientists from Switzerland and Russia, the issue on the abstract or the causal nature of cession is disputable.

Keywords: cession, creditor, debtor, cession contract

\section{Introduction}

The division of legal deals into causal and abstract refers to the deals in which one of the participants is assigned a material valuable or an allotment. The assignment always has some legal basis (causa - Latin) which legally justifies the act of assignment.

Deals are divided into causal and abstract in legal deals depending on whether the legal basis of the assignment is obvious from the content of the deal or is separated or abstracted from it.

A pledge is a legal deal where one person undertakes to complete for the benefit of another person a specific action or to refrain from it. A pledge establishes a debtor's responsibility to complete the deal and hence establishes the legal relation of the liabilities.

An action deal is a legal deal where the existing subjective right is passed, encumbered, altered or terminated.

The determination of the essence of the cession contract and the division according to the aforementioned criteria (abstract or causal, pledge or action deal) is important because the validity and legal effect of the cession contract depend on it.

\section{Discussion}

The cession contract is directed at the transfer of a claim from the cedent to the cessionary. This transfer distinguishes it from the liability deal, which leads to the appearance of liabilities between the parties. Since deals, which mediate the transfer of rights, correspond to all the action deal features, the cession contract is traditionally viewed as an action deal with the help of which the cedent deals with their claim (Crome C. 1902; Tuhr.A. 1925).

Unlike the majority of the civil rights science representatives, V. Belovs defines the cession as „a contract, according to which one party (the cedent) undertakes in front of another party (the cessionary) at the specified time to transfer (to make concessions) the right of claim belonging to him against a third party - the debtor on a condition that he will be responsible for the invalidity of the transferred claim" (Белов В.А.1999). In this way, in the author's opinion, the cession contract causes not the claim transfer but the appearance of the cedent's liability - to transfer this claim to the cessionary. However this opinion does not correspond to the real essence of things. The cession contract is a legal deal on the claim transfer and is the justification of its transfer. Therefore V. Belovs' attempts to translate the cession contract as a liability deal have to be rejected as such that distort the meaning of this contract. Attribution of the cession to the 
action deal group is challenged by the Russian scholar M. Krotovs (Кротов M.B.2008). He believes that the division of deals in the action and liability rights of Russia has no justification that would allow distinguishing them in the Germanic civil legislation. According to the legal doctrine of Russia, the notion of a deal does not go beyond the limits of the legal fact notion; at the same time the Germanic doctrine in a wider notion of a deal also includes the legal fact and the realisation of rights resulting from it" (Кротов М.B.2008). If in the Germanic doctrine everything happened as M. Krotovs imagines it, then it would have to limit "the wide notion of a deal" only to those cases when rights that are capable of being realized appear from the deal. However in that case the claim cession and the debt forgiveness, which the Germanic legislator has qualified as contracts (Paragraph $1 \S 397$, $\$ 398$ BGB), have to be excluded from the "wide notion of a deal" because their operation means not the appearance of rights but respectively changes in the claim possession and termination of the claim with corresponding debts.

At the same time representatives of the German civil rights science are not yet brave enough to make such an inconsiderate step and prefer to use the notion of a deal which comprises all types of legal effects and almost contradicts the notion of a deal that has formed in the modern civil rights science."

The Russian scholar J. Suhanovs is also against distinguishing the action deal category: „Attempts to make the distinction of contracts (deals) into "property" and "liability", characteristic of the Germanic civil rights science, in our own civil rights look unjustified. The peculiarities of Germanic rights determine the "property" ("action") deal category and the related "abstractness principle" known only to this legal order, and these are not generally accepted or in any way practiced on a large scale approaches, but their introduction is not determined by any serious practical needs" .

In his other work he specifies that Germanic constructions of „property contracts” and "action deal..." "...are not known to the valid legislation (of the Russian Federation) and hence they cannot have a real practical sense..." (Суханов E.A.2006) In a similar way the author considers and accordingly qualifies claim cessions as an action deal. It is shown that the notion of "action deal" which has been worked out in detail by representatives of the Germanic civil rights science is indeed interesting to the Russian civil rights science because the definition of the notion "action" does not exist in either Russian or Germanic legislation. However that is why the practical sense of distinguishing this legal figure is not lost. The legislator of Russia and our own land, for example, does not operate with the notion of abstract and causal deal. Does it not mean that such classification does not have a real practical sense? Furthermore, the construction of "action deal (action)" is not the property of only Germanic law. It is also used by representatives of the civil rights science of Switzerland (Tuhr.A.1925) and Austria (Koziol H., Welser R.2001), who recognize the action deal, namely, cession (Keller M., Schöbi Ch.1985; Gauch P., Schluep W., Schmid J., Rey H.1998).

We cannot say that the notion of action deal is unknown to the civil rights science of Latvia either. E. Kalninšs defines the action deal as follows: "The action deal is a legal deal with which the existing subjective right is transferred, encumbered, altered or terminated (Kalninš E.2005). K. Balodis speaking of pledge (liability - V. N.) and action deals specifies: "The most common action deal is transfer of movable property to the possession (Civil Law. Article 987). When transferring movable property to the possession, an expropriation agreement is fulfilled, which is a pledge. Action deals are also - in the liability right part of the Civil Law - a regulated claim right cession (Civil Law. Article 1793) and a cancellation agreement (Civil Law. Article 1862)." (Balodis K.2007) In the Russian literature attempts have been made to generally distinguish deals into actions and liability deals (Черепахин Б.Б.1962; Тархов В.А.1998; Бекленищева И.В.2006), qualification of cession as an action deal has been made (Гражданское право . Под редакцией М.М. Агаркова и Д.М. Генкина.1947), effects of simultaneous property or liability deal conclusion have been distinguished from the side of the represented and the representative with regard to the same subject (Рясенцев B.A.2006) еtc.

That is why discussions of $\mathrm{J}$. Suhanovs have been subjected to fair criticism from Russian authors who pointed to the necessity of qualification for action deals with regard to transfer of property to the possession and for the claim cession (Крашенинников Е.A.2007).

Conclusion of several contracts which determine the liability to transfer individually specified property into possession is permissible (e.g., several purchase agreements of one and the same item). Furthermore, the debtor can only once deal with the rights of ownership to this item to fulfill the undertaken liabilities, and with the transfer of the item to the possession of one of the creditors, the claim rights of other creditors disappear and instead rights to claim damages appear. The cession is analogous: the person who has undertaken liabilities to transfer one and the same claim to different persons has rights to make only one valid claim cession. For creditors who are not in the first cessionary role in the claim transfer liability general default consequences take effect.

The nature of the cession contract action has to be taken into account also when solving the question about the possibility to conclude a cession contract as a contract for the benefit of a third party. Giving an affirmative answer to this question, K.Larenz notes that the creditor can according to the contract with the debtor take action on a claim only for the benefit of a third party, which becomes the third cedent legatee, but has also the right to refuse the claim obtained without 
any help from their own side (Larenz K.1987). Furthermore, the following practical need for the cession contract remains unclear. If one insists on its permissibility only to make the debtor bound with the change of creditor, then the construction defended by K.Larenz can be changed with the creditor or debtor contract because the claim cannot be ceded without the agreement of the latter (Nörr K.W., Scheyhing R., Pöggeler W.1999).

Furthermore, the Russian legislator, following the Germanic legislator example, constructs the contract for the benefit of a third party as a liability deal and accordingly applies this construction only to liability deals. Therefore it is necessary to agree with the authors who believe that contract construction for the benefit of a third party cannot be applied to the cession contract (Nörr K.W., Scheyhing R., Pöggeler W.1999).

Many civil rights science representatives, wanting to emphasize the difference of cession from a deal, which it was based on, compare it to the property transfer to the possession of another person (by tradition) . It is known that F.Savinji defined tradition as contract "however not liability but the property ones that are radically different from the liability contract (selling, exchange etc), which can serve as its justification and largely indeed be its foundation and before it" (Савиньи Ф.К.1876).

Claim session is sometimes also called property contract. Permissibility of the use of such terms is explained by the fact that the word „property" has derived from the word „res”, which in the law of pandectae meant not only material property but any object in general (Nörr K.W., Scheyhing R., Pöggeler W.1999) . Indeed, the division of property into physical and incorporeal was already realised by the Roman lawyers, and it is still preserved in ABGB $\S 353$, which defines property as „everything that belongs to anyone, all their physical and incorporeal items". The clause 841 of the Civil Law of Latvia defines that items are physical and incorporeal. Incorporeal items are different personal, property and liability rights, as long as they are parts of the property.

At the same time the division of property according to the Russian scholar J.Vasjkovskaja "has no practical sense, and it can only lead to misunderstandings, promoting application of the norms which concern things with regard to things that need completely different norms" (Васьковский E.B.2003). It is thought that one of such misunderstandings is the construction of "property rights to the claim", which directly concerns cession rights. For example, F.Leonhard, discussing the question of identity of a claim that belonged to the cedent to the claim received by the cessionary, noted that as a result of a cession „only rights of control of the claim change, which can be better and more meaningfully described as property" and that "for the contract that transfers claim, property right principles work just as well" (Leonhard F.1929). Describing the cession contract as a property contract, the author wanted to emphasize that the cession contract as well as property transfer to the possession does not create liabilities, it is different from the legal justification, is abstract and valid if the main deal is invalid.

However complete equation of the action with claim process (by cession) with the property rights exemption would mean that to receive the claim an agreement on "the transfer of right of ownership" as well as the cession of the claim itself would be necessary, that is two action deals, because two rights can be seen here, hence two action subjects. The Latvian, as well as Germanic and Russian legislator, all discuss this process differently and demand only the cession to receive the claim, not knowing anything about the transfer of "its rights of control".

Hence, as K.Larenz fairly notes, discussion of the action with claim as the exemption of the right of ownership has caused unnecessary and confusing duplication of rights. What F.Leonhard and his followers call "the right of ownership for claim", is in fact the belonging of the claim to the creditor, which can be called "absolute" in the sense that in its nature the relative claim right belongs only to the creditor and no one else. Describing the cession contract operation, one has to speak exactly about changes in claim belonging but not about the transfer of absolute claim right" (Larenz K.1987).

This way, to avoid misunderstandings, it is reasonable to agree with the civil rights science representatives who point to the unacceptability of identification of the action (action deal) with the property deal notion (Sohm R.1905). As A.Tuhr notes, even though cession has more similarity to property transfer than liability contract, it cannot be denoted as a property contract because this notion has to be limited by the property right changes (Tuhr.A.1925). G.Lüke expresses the same opinion, indicating that the cession „is an action but not a property deal because its subject is not a property right but a claim" (Lüke G.1995).

Causing the transfer of the ceded claim, the cession contract causes the increase of the cessionary's property at the expense of the previous creditor's property. This way a claim cession is an assignment (assignment deal) (Zuwendung) (Crome C.1902; Tuhr.A.1925; Oser H., Schönenberger W.1925).

D.Tuzovs has excluded the cession from the assignment list on the basis that "it causes only the transfer of claim rights but not the real property transfer" (Тузов Д.О.2006). Such qualification of the cession J.Krašeninnikovs evaluates as vulgarization of the classic study of assignment (Крашенинников E.A.2006). Due to this criticism D.Tuzov has specified his position and began to mean by property assignment „only real assignment, such as cash payment or item transfer, other increase in real property or any other benefit (namely, as a result of completion of work or service), which 
does not mean only the claim transfer that is still to be made (for example in the case of cession)" (Тузов Д.0.2007). Such a specification hardly explains the situation because it gives an impression as if together with the "real" assignment there were also some "unreal" assignments that do not cause a "real" property increase etc. At the same time, the action deal, with the help of which translative transfer of the claim is performed, fits the definition of assignment relatively well. (Tuhr A.1914). The cessionary's property increase as a result of the claim cession is relatively real: the ceded claim can serve as the cessionary's action subject; it is included in their property mass; collection can be directed at it etc. Therefore the qualification of the cession as an assignment is not subjected to any doubts.

Among assignments abstract and causal deals are distinguished (Palandt 0.2004). Therefore this qualification is also applicable to the cession contract.

If the cession contract is constructed as an abstract deal, then its validity does not depend on the presence or absence of causa cessionis. The opinion on the abstract nature of the cession contract is absolutely prevalent among representatives of the Germanic civil rights sciences. On the contrary, in the civil rights science of Austria this contract, based on the positive rights prescriptions, is traditionally characterised as a causal deal (Koziol H., Welser R.2001). Among the civil rights science representatives of Switzerland the question of the abstract or causal nature of the cession is arguable.

An opinion on the abstract nature of the claim cession is also expressed in the law of Russia. The following facts testify to this opinion:

1. Paragraph 1 of the Clause 1 of the Article 382 of the Russian Federation's Civil Code does not mention a justification of the claim cession contract as a necessary requirement for its validity. In the essence of the law this contract can be fulfilled according to a whole spectrum of justifications. Causa cessionis is a part of the deal, on the basis of which the claim cession is fulfilled. Most often such a deal is a causal liability contract (e.g, purchase claim contract). With regard to the cession contract, it serves as the main or causal deal. The conclusion of the cession contract and the causal liability contract in its basis is usually performed simultaneously, that is the liability to transfer a claim is fulfilled already at the moment of conclusion of the obligatory contract. They are designed as one document, which in practice is called the claim cession contract. Together with the expression of the parties' will to transfer a claim, the justification is also provided, according to which the cession is made. It can be called, for example, a claim purchase contract and contain the agreement of the parties on the claim transfer. In any case clear boundaries must be made between the cession contract and the causal deal in its basis (Dernburg H.1899; Crome C.1902). Their unity is only seeming. This condition is not always taken into account in the civil rights science, and it leads to an incorrect interpretation of the role of both types of deals. For example, M.Agarkovs, pointing to the necessity to distinguish the claim cession action deal and the liability deal, due to which the cession is made, at the same time states that "the action deal often coincides with the liability deal, being its component. For example, an agreement of parties on selling the debt claim also includes an agreement on its transfer to a new creditor".

2. From the content of Article $\mathbf{1 1 0 6}$ of the Russian Federation's Civil Code it follows that the cession contract is recognised as valid also if the main deal does not exist or is invalid (e.g., as a result of its inferiority). The operation of the cession contract is not destroyed if there is no liability for the realisation of which it was concluded or if this liability is invalid. It can only be disposed of using the claim provided in the Article 1106 of the Russian Federation's Civil Code. Since the operation of the cession contract does not depend on the agreement which is in its basis or on validity, one has to admit that the legislator of the Russian Federation constructs this contract as an abstract deal.

A similar interpretation of the cession contract as an abstract deal is reflected in the Civil Law of Latvia.

Practically significant effects of the abstract cession contract are the elevated turnover ability of the ceded claim (Larenz K.1967) and the withdrawal of the debtor's right to express objections, where the objections are the result of a causal deal between the cedent and the cessionary (Crome C.1902).

However abstractness is not a necessary cession contract feature. By the will of the parties of this contract its validity can be made dependent on the realisation of causa cessionis. This happens when the cession contract is concluded on a condition.

If the realisation of causa is a deferring condition of the cession contract (e.g., fulfilment of counter-liabilities on the part of the cessionary as a condition for the cession contract to become valid), then it becomes valid only after fulfilment of this condition. If the loss of justification is made a cancellation condition of the claim cession (e.g., security liability fulfilment in the case of security cession), then when this condition sets in, the creditor status of the cedent is restored.

There is an opinion that the exclusion of the cession contract abstractness can be also realised by other means, namely, using the rules on invalidity of a part of the deal. One cannot agree to that. As it is fairly noted in the literature, 
this method leads to elimination of the abstractness principle, which is the basis of regulation of the claim cession legislation (Nörr K.W., Scheyhing R., Pöggeler W.2004).

From the point of view of the causality principle, the presence of justification and validity are entirely important conditions of the validity of the cession contract. For example, if causa cessionis is invalid, the cessionary does not receive the claims (Keller M., Schöbi Ch.1985).

Expressions in favour of interpretation of the cession contract as a causal deal can be seen in Russian literature.

I.Novickis substantiates this opinion as follows: „With regard to abstractness of claim rights there are no guidelines in the law, therefore there is no basis to recognise it as abstract" (Новицкий И.Б., Лунц Л.А.1950). The author does not explain which law guidelines exactly are meant.

B.Haskelbergs and V.Rovnijs recognise the causal nature of the cession when they pronounce it an auxiliary deal

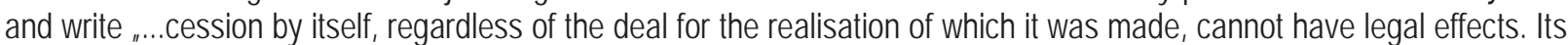
direction is mainly expressed in the contract, which can provide for the transfer of rights on different condition, including payment conditions (purchase, exchange agreements) or on conditions that do not provide for compensation (gift agreement)" (Хаскельберг Б.Л.,2004).

The mentioned opinions contradict the Article 1106 of the Russian Federation's Civil Code, from which it follows that the cession by itself causes the transfer of claim rights even if the deal that was in its basis is invalid.

Justifying the causal nature of the cession, M.Krotovs mentions the following argumentation: the cession contract is a deal the legal result of which is transfer of claim from the creditor to a third party; because the aim of the cession is to change the creditor in the liability, the absence of such an aim makes the cession an invalid deal. From the aforementioned it follows that by the cession contract causality the author in fact means the dependence of the transfer act on the correspondence of the expression of will of the cedent and the cessionary to their true will. However if one interprets causality in such a way, the distinction of deals into abstract and causal becomes unnecessary because all deals will be causal. It is easy to notice that in his discussions M.Krotovs confuses two different notions: the aim of the cession contract, namely, its direct result which the parties anticipate in their consciousness, and the justification of this contract. Of course if the aim of the cession contract parties was not to cause claim transfer, then such contract is invalid. However in this case we are dealing with invalidity of not the causal but seeming or unreal cession contract. The aforementioned opinions of M.Krotovs have no relation to the abstractness and causality of the cession contract in its traditional interpretation, and therefore they cannot undermine the opinion being defended here on abstractness of the cession contract.

Some civilians of Switzerland have expressed doubts about the usefulness of construction of the cession contract as an abstract deal. For example, for them it is "difficult to understand why the claim has to be transferred to another person even though the parties did not wish for it" (Gauch P., Schluep W., Schmid J., Rey H.1998). The authors are missing the obvious fact that the transfer of claim from the cedent to the cessionary according to the cession contract provides for the expression of the parties' will, which are directed at the accomplishment of these effects. If there are no such expressions of will, there is no cession contract either.

Further the authors note that increasing the turnover ability of unsecured claims, which is the aim of construction of the cession contract as an abstract deal, is not the cession rights task (Gauch P., Schluep W., Schmid J., Rey H.1998). Furthermore, the condition that the further development aim of this institution is exactly such increase of turnover ability of claims is not taken into account.

Analogous notes can be made with regard to the position of V.Baibaks who states that construction of the cession as an abstract contract is practically useless and notes that in the case of the bill, there is a special mechanism which ensures the stability of claim turnover at the expense of abstractness of the transfer order deals. The author asks himself a question: why then attach an abstract nature to a general civil cession? If the creditor needs to assign elevated turnover ability to the cash claim, they can achieve "dressing up" of the liability in the form of a bill and fully enjoy all the advantages and disadvantages of abstractness of the bill transfer claim. However to impose the cession abstractness on all liability owners seems excessive. Such state to a certain extent contradicts the principle of legal means economy because two order deals appear that have the same advantages and disadvantages; in this state of things the cession abstractness in the conditions of endorsement abstractness also contradicts the civil rights dispositivity principle. V.Baibaks is missing several conditions. Firstly, the bill claim turnover ability is achieved mainly not by the "endorsement abstractness" - it would be more correct to say: by the abstractness of the endorsed bill transfer to the possession, - but by the fact that the endorser receives the rights that result from endorsed bills by initial acquisition but not by acquisition of rights, like it happens in the case of cession. For example, it means that, transferring the bill after its endorsement, the bill owner has significantly fewer objections to the bill holder claims than the debtor has after the ceded claim. Therefore it is unlikely that any debtor will allow the creditor "to achieve facilitation of dressing up a liability in the form of a bill". 
Secondly, as has been noted earlier, the claim cession principle of abstractness is not imperatively imposed: the cedent and the cessionary can make the cession operation dependent on the validity of the causal deal.

\section{Conclusions}

The author arrives at the conclusion that in the translation of the legal theory and legislation of different countries there are different opinions on the qualification of the cession contract. The opinion about the abstract nature of the cession contract is absolutely prevailing among representatives of the Germanic civil rights sciences. In the Austrian civil rights science this contract, on the basis of positive rights prescriptions, is traditionally characterized as a causal deal. Among the civil rights science representatives of Switzerland and Russia the question of the abstract or causal nature of the cession is arguable. The legislator of Latvia constructs the cession contract as an abstract action deal.

\section{References}

Balodis K.(2007) levads civiltiesībās. Zvaigzne ABC. 173.lpp.

Crome C. (1902) System des deutschen bürgerlichen Rechts. Tübingen und Leipcig. , Bd.2, S.322;

Gauch P., Schluep W., Schmid J., Rey H. (1998) Schweizerisches Obligationenrecht. Allgemeiner Teil. 7 Aufl. Zürich, Bd.2, S.294295;316

Kalniņš E. (2005) Tiesisks darījums//Privāttiesību teorija un prakse. Raksti privāttiesībās. Rīga. Tiesu namu aǵentūra, 143.lpp.

Keller M., Schöbi Ch.(1985) Das schweizerische Schuldrecht. 2Aufl. Basel und Frankfurt a.M., Bd.4. S.45;

Koziol H., Welser R.(2001) Grundriss des bürgerlichen Rechts. 12 Aufl. Wien, Bd.1. S.116; 118

Larenz K. (1987) Lehrbuch des Schuldsrechts. 14 Aufl. München, Bd.1, S.233; 573-575;577

Leonhard F.(1929) Allgemeines Schuldrecht des BGB. München und Leipzig, S.662, 672

Lüke G. (1995) Grundfragen des Zessionrechts//Juristische Schulung, S. 90;

Nörr K.W., Scheyhing R., Pöggeler W.(1999) Sukzessionen: Forderungszession, Vertragsübernahme, Schuldübernahme. 2. Aufl. Tübingen, S. 9-11;18 mit Anm. 40

Oser H., Schönenberger W. (1929) Das Obligationenrecht Halbbd. I: Art.1-183., 2 Aufl. Zürich, S.712;

Palandt O. (2004) Bürgerliches Gesetzbuch. Kurzkommentar. 63 Aufl. München, S.75;587;

Sohm R. (1905) Der Gegenstand. Ein Grundbegriff des Bürgerlichen Gesetzbuches. Leipzig, S.8

Tuhr.A. (1925) Allgemeiner Teil des schweizerischen Oblihationenrechts. Tübingen, Halbbd.2, S.171-176; 716;

Белов В.А.(1999) Вексельное законодательство России. Научно - практический комментарий. 2-е изд. Москвас. 418

Васьковский Е.В.(2003) Учебник гражданского права. Москва. С.117

Гражданское право . Под редакцией М.М. Агаркова и Д.М. Генкина.(1947) Т.1. с. 398; Серебровский В.И. Договор страхования жизни в пользу третьего лица // Ученые труды ВИЮН. Вып.9 с.350

Крашенинников Е.А.(2007) Распорядительные сделки // Сборник статей памяти М.М.Агаркова. Ярославль. с. 23-24

Крашенинников Е.А.(2006) Общая характеристика предоставлений// Очерки по торговому праву. Ярославль. Вып.13.с.23

Кротов М.В.(2008) Рецензия на «Сборник статей к 55- летию Е.А. Крашенинникова // Закон. № 1, с.192

Новицкий И.Б., Лунц Л.А.(1950) Общее учение об обязательстве. Москва, с.224

Рясенцев В.А. (2006) Представительство и сделки в современном гражданском праве. Москва. с. 130

Савиньи Ф.К. (1876) Обязательственное право. Москва. С 584

Суханов Е.А. (2006) О видах сделок в германском и российском гражданском праве// Вестник гражданского права. № 2. с. 23

Тузов Д.О.(2006) О правовой природе традиции// Сборник статей к 55-летию ЕЮАЮ Крашенинникова. Ярославль. Вып.13.с.78

Тузов Д.О.(2007) Теория недействительности сделок: опыт российского права в контексте европейской правовой традиции. Москва. С.334, 335

Хаскельберг Б.Л., Ровный В.В.(2004) Консенсуальные и реальные договоры в гражданском правею 2-е изд. Москва. с.81 